\title{
Effect of the kappa-casein gene polymorphism, breed and seasonality on physicochemical characteristics, composition and stability of bovine milk
}

\author{
Bruno Garcia Botaroํㅜ, Ygor Vinícius Real de Lima ${ }^{2}$, Cristina Simões Cortinhas ${ }^{1}$, Luís Felipe \\ Prada e Silva ${ }^{1}$, Francisco Palma Rennó ${ }^{1}$, Marcos Veiga dos Santos ${ }^{1}$ \\ ${ }^{1}$ Departamento de Nutrição e Produção Animal, Faculdade de Medicina Veterinária e Zootecnia, USP, Av. Duque de Caxias Norte, 225, \\ CEP: 13635-900, Pirassununga, SP. \\ ${ }^{2}$ Centro Universitário Anhanguera, Faculdade de Medicina Veterinária. Rua Waldemar Silenci, 340, Leme, SP.
}

\begin{abstract}
The objective of this study was to evaluate the effect of genetic polymorphism of kappa-casein, breed and seasonality on the physicochemical characteristics, composition and stability of milk in commercial dairy herds. A total of 879 milk and blood samples were collected from 603 Holstein and 276 Girolando cows, obtained during rainy and dry seasons. Milk samples were analyzed to determine the physicochemical characteristics, composition and ethanol stability, while blood samples were subjected to polymerase chain reaction to identify the kappa-casein genotype. The frequencies of genotypes $\mathrm{AA}, \mathrm{AB}$ and $\mathrm{BB}$ of $k$-casein were respectively, 66.83, 31.84 and $1.33 \%$ for Holstein, and $71.38,27.90$ and $0.72 \%$ for the Girolando cows, respectively. The A allele was more frequent than the B allele, both for Holstein (0.827 and 0.173 ) and Girolando cows (0.853 and 0.147), respectively. Cows of $\mathrm{AB}$ and BB genotypes showed a higher milk fat content compared to the AA genotype. There was an interaction between breed and seasonality on the concentration of milk urea with higher values for Holstein and Girolando cows in the rainy and dry season, respectively. The levels of lactose, total solids, crude protein, true protein, casein and the casein:true protein ratio were higher during the dry season, while during the rainy season, the somatic cell count and milk urea concentration were higher. There was no association between milk stability and k-casein genotypes, but Holstein cows showed higher milk stability than Girolando cows, and milk was more stable during the rainy season than during the dry season.
\end{abstract}

Key Words: crioscopy, dairy cow, ethanol stability test, genetic variant, polymerase chain reaction, titratable acidity

\section{Efeito do polimorfismo do gene da kappa-caseína, da raça e da sazonalidade sobre as características físico-químicas, de composição e de estabilidade do leite bovino}

RESUMO - Objetivou-se avaliar o efeito do polimorfismo genético da kappa-caseína, da raça e da sazonalidade sobre as características físico-químicas, a composição e a estabilidade do leite bovino de rebanhos comerciais. Foram coletadas 879 amostras de leite e de sangue de 603 vacas da raça Holandesa e 276 da raça Girolando, obtidas durante as estações seca e chuvosa. As amostras de leite foram analisadas para determinação de características físico-químicas, de composição e de estabilidade ao etanol, e as amostras de sangue foram submetidas à reação em cadeia da polimerase para identificação do genótipo da kappa-caseína. As frequências dos genótipos AA, AB e BB da kappa-caseína foram, respectivamente, de 66,83; 31,84; e 1,33\% para a raça Holandesa e 71,38; 27,90; e 0,72\% para a Girolando. O alelo A foi mais frequente que o B, tanto para a raça Holandesa $(0,827$ e 0,173$)$ quanto para a Girolando $(0,853$ e 0,147$)$. Vacas dos genótipos AB e BB apresentaram maior teor de gordura no leite que as do genótipo AA. Houve interação entre raça e sazonalidade para a concentração de ureia do leite, com maiores concentrações para as raças Holandesa e Girolando, respectivamente, nas estações chuvosa e seca. Os teores de lactose, sólidos totais, proteína bruta, proteína verdadeira e caseína e a relação caseína/proteína verdadeira foram maiores durante o período seco, enquanto, durante a estação chuvosa, a contagem de células somáticas e os teores de nitrogênio ureico no leite foram maiores. Não houve associação entre a estabilidade do leite e os genótipos da kappacaseína, no entanto, o leite de vacas Holandesas é mais estável que o de vacas Girolando e, durante a estação chuvosa, apresenta maior estabilidade que na estação seca.

Palavras-chave: acidez titulável, crioscopia, prova de resistência ao álcool, reação em cadeia da polimerase, vaca leiteira, variante genética 


\section{Introduction}

Kappa-casein ( $k$-casein) represents up to $12 \%$ of the total casein in bovine milk (Fox \& Brodkorb, 2008). This protein is encoded by a trait locus at chromosome 6 and comprises a sequence of 162 amino acids (Rijnkels, 2002). The two main $k$-casein variants, $\mathrm{A}$ and $\mathrm{B}$, differ in the amino acids at positions 136 (Thr for Ile) and 148 (Asp for Ala) (Alexander et al., 1988).

Reports on the association of $k$-casein genetic variants and milk composition have somewhat conflicting results (Molina et al., 2006; Hallen et al., 2008). Ng-KwaiHang et al. (1990) reported changes in milk protein concentrations due to the $k$-casein genotypes $\mathrm{A}$ and $\mathrm{B}$. However, Haenlein et al. (1987) found no effect of $k$-casein variants on milk crude protein, while others reported higher contents of protein (Stevanovic et al., 2000) and caseins (Molina et al., 2006) in allele B $k$-casein cow milk.

Heat stability of milk refers to the timeline in which heatinduced changes occur in milk, i.e. coagulation, under defined pH and temperature (Singh, 2004). The ethanol stability test has been widely adopted by the dairy industry to evaluate this characteristic (O’Connell et al., 2001). However, similarly to milk composition, associations of $k$-casein genotypes and milk stability have also shown discordant outcomes. Imafidon et al. (1991) and Robitaille (1995) suggested that $k$-casein AA genotype milk is more stable in the ethanol test, while Paterson et al. (1999) found higher stability in $k$-casein BB milk.

Factors other than genetic polymorphism of milk proteins, e.g. seasonal variations (Lindmark-Mänsson et al., 2003; Teixeira et al., 2003) and animal breed (Auldist et al., 1998; Arunvipas et al. 2003) are also associated with milk compositional changes and their effects on milk heat stability (Botaro et al., 2007), but their interaction with $k$-casein genetic variants has not been studied yet. Moreover, results on the association between $k$-casein genetic variants of Girolando cows and milk composition of this Bos indicus breed are still rare (Teodoro \& Madalena, 2003).

Thus, the objective of this study was to evaluate the effect of genetic polymorphism of $k$-casein on the physicochemical, composition and stability of milk produced by Holstein and Girolando cows, during the dry and rainy seasons.

\section{Material and Methods}

Eleven commercial dairy herds from the Pirassununga region, São Paulo state, Brazil, were selected for this experiment. Six herds consisted of Girolando (crossbred
Holstein-Zebu cows) and five of Holstein cows. A total of 879 milk and blood samples were taken from 603 Holstein and 276 Girolando lactating cows during two dry seasons and two rainy seasons (Sampling period \#1, September and October, 2003; Sampling period \#2, June and July, 2004; Sampling period \#3, November and December, 2004; and Sampling period \#4, January and February, 2005).

The rainy season was defined as the period between November and April, and the dry season, as the period between May and October. The classification between rainy and dry seasons was based on two well-established seasons in Southeast Brazil, which have a direct impact on feed availability and milk composition of dairy herds. This procedure separated the effects of seasonality on milk composition among the studied herds.

In each dairy herd, the sampled cows had to fulfill the following criteria: first to third lactation, and between 30 to 250 days of lactation. Girolando cows should be 1/2, 3/4 and 3/8 Zebu/Holstein. Cows with clinical mastitis, or submitted to mastitis treatment less than two weeks before milk sampling, were excluded from this study. Additionally, at the moment of milk sampling, information of each selected dairy cow was registered, such as age, days in lactation and type of feeding system (pasture, supplemented pasture or total mixed ration).

Milk samples were collected during the morning milkings in order to represent the whole milking of each animal. A hundred $\mathrm{mL}$ of milk were collected directly from the collection bucket immediately after the cow was milked, or during milking, using flux measurement devices connected to the milk line. Collected samples were split into two flasks: one treated with bronopol (Boots Microcheck, Nottingham, England) was used for fat, lactose, total solids, milk urea nitrogen and somatic cells count determinations; and the other was cooled and stored until physicochemical characteristics analysis and the ethanol stability test up to six hours after collection. Milk physicochemical characteristics $-\mathrm{pH}$, titratable acidity $\left({ }^{\circ} \mathrm{D}\right)$ and cryoscopy $\left({ }^{\circ} \mathrm{H}\right)$ - were determined as described by Pereira et al. (2001).

Milk samples were sent to the Clínica do Leite ("Luiz de Queiroz” Agricultural College-ESALQ, Piracicaba, Brazil) to determine fat, lactose and total solids using the Bentley 2000 equipment (Bentley, Chasca, MN, USA), according to the infrared absorption methodology (Bentley, 1995a). Milk urea nitrogen (MUN) was determined by the colorimetricenzymatic method (Bentley, 1998), using the Chemspec 150 (Bentley Instruments Inc., Chasca, MN, USA). Somatic cells were electronically counted with the Somacount 300 equipment (Bentley, Chasca, MN, USA), according to the cytometry flow methodology (Bentley, 1995b), and 
converted to logarithm scale (LogSCC). Milk protein fractions were analyzed for total nitrogen (AOAC, 1990; method 33.2.11; 991.20), non-casein nitrogen (NCN) (Lynch et al. 1998) and non-protein nitrogen (NPN) concentrations (AOAC, 1995; method 33.2.12; 991.21). In order to express the results as protein equivalent, total nitrogen values found in the milk analyses were multiplied by 6.38 (Barbano et al. 1990). Milk true protein (MTP) and casein concentrations were obtained by difference according to: crude protein $-(\mathrm{NPN} \times 6.38)=$ milk true protein, and MTP $-(\mathrm{NNC} \times 6.38)=$ casein, respectively.

Milk stability was determined by the ethanol test according to Davies \& White (1958), with alcoholic solutions at 70, 76, 80 and $84^{\circ} \mathrm{GL}(\mathrm{v} / \mathrm{v})$. Given results were classified as stable (without coagulation) or unstable (with coagulation), according to the alcohol solution used.

To determine the genetic polymorphism of kappacasein, $10 \mathrm{ml}$ blood were collected from peripheral blood vessels, in heparinized sterile glass tubes, from each animal selected, which were frozen at $-20^{\circ} \mathrm{C}$ until the time of analysis.

DNA was extracted from each blood sample accordingly to Sambrook et al. (1989). Extracted DNA samples were submitted to PCR (polymerase chain reaction) amplification. Primers used for DNA amplification were synthesized by Invitrogen ( ${ }^{\circledR}$ Custom Primers (Inivitrogen Corp., Carlsbad, California, USA), according to the sequence described by Cronin \& Cockett (1993):

\section{Forward-5'GTGCTGAGYAGGTATCCTAG3'}

Reverse - 5'GTAGAGTGCAACAACACTGG3'

These primers amplified a $99 \mathrm{bp}$ region in exon IV of the $k$-casein gene. The amplified region comprises the nucleotide substitution responsible for differentiating A and $\mathrm{B}$ genetic variants of the gene. Each amplification reaction consisted of PCR buffer $1 \mathrm{X}$ ( $\mathrm{KCl} 500 \mathrm{mM}$, Tris-Cl pH $8.3100 \mathrm{mM}), 0.1 \mu \mathrm{L}$ of the described primers, $2 \mu \mathrm{L}$ dNTP $(0.125 \mathrm{mM}), 0.1 \mu \mathrm{L}$ Taq polymerase(Cenbiot/RS, PHN/MG), $0.75 \mu \mathrm{L} \mathrm{MgCl}_{2}$ (Cenbiot/RS, PHN/MG), $5 \mu \mathrm{L}$ of DNA and mili-Q water qsp $25 \mu \mathrm{L}$. In all amplified reactions, a control (blank/no-DNA) was used to confirm the absence of contamination during the analysis. The amplification process of each reaction was carried on a PTC 100-MJ Research thermocycler ${ }^{\circledR}$ (MJ Research, Inc., Watertown, Massachussets, USA). Each reaction was based on the following program: inicial five- minute denaturation at $95^{\circ} \mathrm{C}$ followed by 35 cycles at $95^{\circ} \mathrm{C}$ for one minute, $57^{\circ} \mathrm{C}$ for one minute and $72^{\circ} \mathrm{C}$ for three minutes, with final extension at $72^{\circ} \mathrm{C}$ for five minutes, followed by five minutes at $4^{\circ} \mathrm{C}$.

Targeted DNA fragment amplification of the samples was confirmed in $2 \%$ agarose gel electrophoresis, immersed in $1 \mathrm{X}$ TBE buffer for 40 minutes at 100 Volts. The PCR product $(20 \mu \mathrm{L})$ was then submitted to the restriction fragment length polymorphism process (RFLP), and digested by the restriction enzyme Hind III (Invitrogen Corp., Carlsbad, California, USA), according to Cronin \& Cockett (1993), in order to show the presence of either AA, AB or BB genotypes. Hind III cleaved amplified fragments in 99 bp (AA genotype), 65 and 34 bp (BB genotype), or a combination of both (AB genotype), with 34, 65 and 99 bp. The DNA template was amplified and cleaved in PCR plates. Thus the presence of the heterozygous $A B$ confirmed the effectiveness of the RFLP process. After identifying the $k$-casein gene, the genotype and allele frequencies for the studied herd were obtained.

Data were submitted to descriptive statistics (arithmetic mean and standard mean error) by PROC MEANS of SAS (SAS, 2001) and analysis of variance was performed using PROC GLM. In order to prepare data for statistical analysis, the cows were distributed according to $k$-casein genetic variants (AA, BB and AB), breed (Holstein and Girolando) and seasonality (rainy and dry seasons). Analysis of variances were made using a mathematical model, in which dependent variables were considered the physicochemical characteristics of milk (acidity, $\mathrm{pH}$ and freezing point) and composition, and the fixed effects were the $k$-casein variants, breed and seasonality:

MC, $\mathrm{PC}_{\mathrm{ilmn}}=\mu+\mathrm{H}_{\mathrm{i}}(\mathrm{B})_{\mathrm{l}}+\mathrm{B}_{\mathrm{l}}+\mathrm{P}_{\mathrm{m}}+\mathrm{S}_{\mathrm{n}}+\mathrm{P}_{\mathrm{m}} * \mathrm{~B}_{\mathrm{l}}+\mathrm{P}_{\mathrm{m}} * \mathrm{~S}_{\mathrm{n}}$ $+\mathrm{B}_{1} * \mathrm{~S}_{\mathrm{n}}+\mathrm{P}_{\mathrm{m}} * \mathrm{~S}_{\mathrm{m}}+\mathrm{e}_{\mathrm{ilmn}}$, where $\mathrm{MC}=$ milk composition and $\mathrm{PC}=$ physicochemical; $\mu=$ overall average of the characteristic; $\mathrm{H}_{\mathrm{i}}(\mathrm{B})_{\mathrm{l}}=$ [Breed $(\mathrm{l}=$ Holstein and Girolando $)$ nested with $\mathrm{H}=$ herd ( $\mathrm{i}=1$ to 11 )]; $\mathrm{P}_{\mathrm{m}}=k$-casein genotypes $(\mathrm{m}=\mathrm{AA}, \mathrm{AB}$ and $\mathrm{BB}) ; \mathrm{S}_{\mathrm{n}}=$ seasonality $(\mathrm{n}$ = rainy and dry season); $\mathrm{e}=$ random error.

The association of milk stability and studied factors was analyzed by the chi-square test $\left(\chi^{2}\right)$ with SAS PROC FREQ. Results were declared statistically different at a level of $5 \%$ significance.

\section{Results and Discussion}

Allele A was found more frequently than B in both breeds (Table 1). Kappa-casein AA genotype was present at a higher frequency for both Holstein (66.38\%) and Girolando (71.38\%) cows, followed by AB (31.84\% and $27.90 \%$, respectively) and $\mathrm{BB}(1.33 \%$ and $0.72 \%$, respectively).

The kappa-casein allele frequencies among the studied animals were similar to those observed by Oner \& Elmaci, (2006), who found frequencies of 0.712 and 0.288 , for $k$-casein A and B, respectively, for Holstein cows. The 
relative genotype frequencies reported by these authors also predominanted for $k$-casein AA (69.75\%), followed by AB (18.54\%) and BB (12\%). Silva \& Del Lama (1997) assessed $k$-casein genotypes of four different Bos indicus breeds (Gir, Guzerá, Sindhi and Nellore) and found that the A allele was most frequently found in all the studied breeds ( $0.95,0.80,0.66$ and 0.97 , respectively).

Milk physicochemical characteristics were not influenced by $k$-casein polymorphism, nor by any interaction among the studied gene, breeds and seasonality (Table 2), and nor by a triple interaction among factors.

No reports about the association of titratable acidity, $\mathrm{pH}$, milk freezing point and $k$-casein genetic variants were found. However, some studies on the differences in amino acid composition expressed by the $k$-casein genetic variants partly explain the structural differences of translated proteins. These changes range from net charge, hydrophobicity, degree of phorphorilation and glycosylation, and can thus partially explain the observed changes in milk protein behavior during thermal processing of dairy products (Ng-Kwai-Hang, 1998).

Milk fat was influenced by $k$-casein variants and was found to be higher in milk of the AB cows, followed by AA and $\mathrm{BB}(3.38,3.25$, and $3.14 \%$ respectively). These results are different from those reported by Ng-Kwai-Hang (1997), who indicated higher fat content, protein and casein in $k$-casein B allele milk. Ng-Kwai-Hang et al. (1990) also observed higher fat content in $k$-casein $\mathrm{BB}$ animals compared to $\mathrm{AA}$ and $\mathrm{AB}$ cows.

Similarly to results reported by Haenlein et al. (1987), total protein was not influenced by $k$-casein variants. However, some authors have demonstrated that the $\mathrm{B}$ allele of $k$-casein in cattle is correlated with increased protein production in milk compared to allele A (Stevanovic et al., 2000; Molina et al., 2006). According to Bobe et al. (1999), this occurs because nucleotide changes that distinguish the $\mathrm{B}$ allele of $k$-casein $\mathrm{A}$ are responsible for the phenotypic expression of $k$-casein protein, which could justify the higher numerical values for the observed levels of milk crude protein, true protein, casein and the casein:true protein ratio of BB $k$-casein animals in the present experiment.

Except for titratable acidity, $\mathrm{pH}$ and fat, the physicochemical characteristics and milk composition were influenced by seasonality (Table 3). Average values for fat content were $3.29 \%$ and $3.30 \%$ during the dry and rainy seasons, respectively. Results are similar to those found by Silva (2003), who described levels of 3.30 and

Table 1 - Distribution of $k$-casein gene and allele frequencies for Holstein and Girolando cows

\begin{tabular}{lcccc}
\hline Breed & & Genotype frequencies & Allele frequencies. $( \pm$ SEM $(\mathrm{a}))$ \\
\cline { 2 - 4 } & Genotypes & $\mathrm{N}$ observed & $\%$ & \\
\hline Holstein & $\mathrm{AA}$ & 403 & 66.83 & $\mathrm{~A}=0.8275 \pm 0.0217$ \\
& $\mathrm{AB}$ & 192 & 31.84 & $\mathrm{~B}=0.1724 \pm 0.0217$ \\
BB & 8 & 1.33 & \\
Girolando & 603 & 71.38 & $\mathrm{~A}=0.8532 \pm 0.0253$ \\
& $\mathrm{AA}$ & 197 & 27.90 & $\mathrm{~B}=0.1467 \pm 0.0253$ \\
& $\mathrm{AB}$ & 77 & 0.72 & \\
\hline
\end{tabular}

(a) Standard mean error, according to Oner \& Elmaci (2006).

Table 2 - Effect of $k$-casein polymorphism on physicochemical characteristics and milk composition

\begin{tabular}{|c|c|c|c|c|c|c|c|}
\hline \multirow[t]{2}{*}{ Variable } & \multicolumn{6}{|c|}{ k-casein polimorphism } & \multirow[t]{2}{*}{$\mathrm{P}$} \\
\hline & $\mathrm{N}$ & AA & $\mathrm{N}$ & $\mathrm{AB}$ & $\mathrm{N}$ & BB & \\
\hline Titratable acidity $\left({ }^{\circ} \mathrm{D}\right)$ & 587 & 16.44 & 252 & 16.53 & 10 & 16.60 & 0.825 \\
\hline $\mathrm{pH}$ & 557 & 6.78 & 248 & 6.779 & 8 & 6.76 & 0.886 \\
\hline Cryoscopy $\left({ }^{\circ} \mathrm{H}\right)$ & 550 & -0.539 & 250 & -0.540 & 9 & -0.539 & 0.935 \\
\hline Fat $(\%)$ & 553 & $3.25 b$ & 247 & $3.38 \mathrm{a}$ & 10 & $3.14 \mathrm{ab}$ & 0.041 \\
\hline Lactose (\%) & 579 & 4.45 & 260 & 4.45 & 10 & 4.47 & 0.950 \\
\hline Total solids (\%) & 570 & 11.78 & 255 & 11.91 & 10 & 11.54 & 0.105 \\
\hline SCC $\left(\times 10^{3}\right.$ cells $\left./ \mathrm{mL}\right)$ & 600 & 245 & 270 & 246 & 10 & 247 & 0.999 \\
\hline MUN (mg/dL) & 584 & 16.01 & 265 & 16.05 & 10 & 15.63 & 0.950 \\
\hline Total protein (\%) & 553 & 3.12 & 244 & 3.11 & 10 & 3.14 & 0.857 \\
\hline Milk true protein (\%) & 522 & 2.90 & 237 & 2.88 & 10 & 2.94 & 0.546 \\
\hline Casein $(\%)$ & 484 & 2.10 & 221 & 2.09 & 8 & 2.16 & 0.808 \\
\hline Casein:MTP & 484 & 0.72 & 221 & 0.72 & 8 & 0.74 & 0.471 \\
\hline
\end{tabular}

a,b Means with different upper case letters differ within the rainy season by Tukey test. 
$3.48 \%$, respectively, in milk samples obtained during the dry and rainy seasons in São Paulo.

Concentrations of total solids (11.67\%), crude protein (3.08\%), milk true protein (2.85\%), casein $(2.01 \%)$ and the casein:true protein ratio (0.70) were lower during the rainy season compared with the dry season. However, Teixeira et al. (2003) found no effect of seasonality on fat and the other milk solids concentration. Moreover, these authors observed that seasonal fluctuations in fat and milk protein showed opposite trends to those seen for milk yield: higher during winter (dry season) and lower in summer months (rainy season). Differences between the seasonality effects on milk composition may be associated with reduced quality and availability of feed provided to animals during dry periods that limit energy supply to the mammary tissue epithelium, and thus, mammary secretion of milk components (Ponce \& Hernandéz, 2001).

Regardless of the fact that the average freezing point observed in this study $\left(<-0,530^{\circ} \mathrm{H}\right)$ is in compliance with the Brazilian milk ordinance (Brasil, 2002), it was lower $\left(-0.541^{\circ} \mathrm{H}\right)$ in the rainy season compared with the dry period $\left(-0.538^{\circ} \mathrm{H}\right)$. Lindmark-Månsson et al. (2003) evaluated milk physicochemical characteristics of Swedish dairy herds and reported effect of seasonality on freezing point values (-0.552 and $-0.541^{\circ} \mathrm{H}$, in the summer and winter, respectively). Schukken et al. (1992), in contrast, reported higher milk freezing point values in summer (June and July), and lower in winter (December and January) of Canadian dairy herds. In São Paulo, Rodas et al. (1999) also observed variation in cryoscopy of milk samples throughout the year and attributed the occurrence to changes in climate, which impacts nutritional management of herds, since lower values are associated with the season in which nutrients are less available in feed.
In the present study, during the dry season, the average SCC was lower and lactose content higher than those observed in the rainy season. In Goiás, Bueno et al. (2005) also observed a reduction of lactose content when SCC increased (342,000 cells/mL). This reduction might occur because of tissue damage and the increased efflux of carbohydrates from the alveolar lumen into the bloodstream (Bansal et al., 2005). Clinical cases of mastitis increase in this period because of greater rainfall and temperature, which increase susceptibility to intramammary infections because the gland is more exposed to adverse environmental conditions and, thus, pathogens (Santos \& Fonseca, 2006).

Holstein cow milk had lower titratable acidity average and higher MUN and crude protein contents than those observed for Girolando cows (Table 4), although no other variable seemed to be influenced by the studied breeds. In the present study, the average fat contents were 3.30 and $3.25 \%$ for Holstein and Girolando cows. Assessing milk composition of Holstein cows, Teixeira et al. (2003) and Ribas et al. (2004) reported average fat concentrations of 3.23 and $3.57 \%$, respectively. In data compiled from 24,299 Gir cows, Verneque et al. (2005) found a fat average of $3.92 \%$, $S D \pm 0.80$.

Milk crude protein of Holstein cows detected in this study (3.13\%) was higher than that of Girolando cows (3.09\%), unlike values described by Teixeira et al. (2003) and Ribas et al. (2004) for Holstein cows, who reported 3.11 and 3.14\%, respectively. Verneque et al. (2005) reported crude protein of $3.31 \%$ for Gir cows, higher than those found in this study.

MUN was the only response in which interaction between breed and seasonality was observed. Milk from Holstein cows showed higher concentrations of MUN

Table 3 - Effect of seasonality on physicochemical characteristics and milk composition

\begin{tabular}{|c|c|c|c|c|c|c|}
\hline \multirow{3}{*}{ Variable } & \multicolumn{6}{|c|}{ Season } \\
\hline & \multicolumn{3}{|c|}{ Rainy } & \multicolumn{3}{|c|}{ Dry } \\
\hline & $\mathrm{N}$ & Mean & SEM (a) & $\mathrm{N}$ & Mean & SEM (a) \\
\hline Titratable acidity $\left({ }^{\circ} \mathrm{D}\right)$ & 308 & 16.68 & 0.108 & 541 & 16.38 & 0.088 \\
\hline $\mathrm{pH}$ & 305 & 6.80 & 0.005 & 508 & 6.77 & 0.005 \\
\hline Cryoscopy $\left({ }^{\circ} \mathrm{H}\right)$ & 289 & $-0.541 * *$ & 0.001 & 520 & $-0.538 * *$ & 0.001 \\
\hline Fat $(\%)$ & 289 & 3.30 & 0.043 & 521 & 3.29 & 0.031 \\
\hline Lactose (\%) & 304 & $4.35 * *$ & 0.013 & 545 & $4.50 * *$ & 0.010 \\
\hline Total solids (\%) & 302 & $11.67 * *$ & 0.056 & 533 & $11.90 * *$ & 0.038 \\
\hline SCC $\left(\times 10^{3}\right.$ cells $\left./ \mathrm{mL}\right)$ & 312 & $288 *$ & 0.035 & 568 & $224 *$ & 0.028 \\
\hline MUN (mg/dL) & 298 & $16.34 * *$ & 0.295 & 561 & $15.85 * *$ & 0.163 \\
\hline Total protein (\%) & 263 & $3.08 * *$ & 0.017 & 544 & $3.14 * *$ & 0.012 \\
\hline Milk true protein (\%) & 227 & $2.85 * *$ & 0.019 & 542 & $2.91 * *$ & 0.012 \\
\hline Casein (\%) & 182 & $2.01 * *$ & 0.023 & 531 & $2.13 * *$ & 0.012 \\
\hline Casein:MTP & 182 & $0.70 * *$ & 0.004 & 531 & $0.73 * *$ & 0.002 \\
\hline
\end{tabular}

(a) Standard mean error. $* \mathrm{P}<0.05 ; * * \mathrm{P}<0.01$. 
during the rainy season than in the dry season (18.02 vs. $15.98 \mathrm{mg} / \mathrm{dL}$ ), while this nitrogen fraction in Girolando milk was higher in the dry period compared with the rainy period (15.54 vs.12.90 mg/dL). This result suggested that the increase in Girolando MUN might be related to inadequate availability of pasture and excessive NPN sources fed to the animals during the dry period. According to Arunvipas et al. (2003), non-nutritional factors, such as breed, stage of lactation and cow pregnancy, milk yield and composition explained $13.3 \%$ of the variability in milk urea nitrogen concentrations.

Table 5 shows the results of milk stability according to $k$-casein polymorphism. A total of 268 out of 879 milk samples (30.49\%) showed instability in the ethanol test, in any of the ethanol solutions. Among the unstable samples, 191 were from $k$-casein AA cows, 75 from the AB genotype and two belonged BB $k$-casein cows. There was no association between the occurrence of sample coagulation and the $k$-casein genotypes $(\mathrm{P}=0.388)$. Therefore, the observed differences in the milk stability and the ethanol stability test expressed only a random variation, without the influence of the studied genotypes $\mathrm{AA}, \mathrm{AB}$ and $\mathrm{BB}$.

The average ethanol concentrations at which the AA, AB and BB milk samples coagulated were 79.16, 78.77 and $84^{\circ} \mathrm{GL}$, respectively. These findings differed from those reported by Feagan et al. (1972), who found higher milk stability among $k$-casein $\mathrm{AB}$ cows, followed by AA and BB cows. Higher stability of AB $k$-casein milk was also observed by Imafidon et al. (1991). Despite the evident differences in behavior of milk when subjected to heat treatment, it is still unclear whether the effect depends only on the conformation of $k$-casein protein transcribed by its gene and its thermal reactivity (Singh, 2004), or on its binding to the beta-lactoglobulin protein contained in the given milk (Imafidon et al., 1991; Robitaille, 1995).

The association between milk stability and the studied breeds was observed $(\mathrm{P}<0.001)$. A total of 465 out of 603 milk samples from Holstein cows (77.11\%) did not clot in the ethanol test. On the other hand, only $52.90 \%$ (146 out of 276) of milk samples taken from Girolando cows were stable (Table 6). Given the conditions of this study, the Holstein cows yielded more stable milk compared to the Girolando cows. This result could be explained by Janu et al. (2007), whose findings indicated that the higher milk yield Holstein cows had the less stable milk.

Milk stability was associated with seasonality $(\mathrm{P}=0.014)$ and was higher during the rainy season compared with the dry season (Table 6). During the dry period, 189 milk samples out of 567 clotted (33.3\%), when $30.49 \%$ were expected to coagulate, while $66.67 \%$ (378 samples) showed no instability during the same period regardless of the

Table 4 - Effect of breed on physicochemical characteristics and milk composition

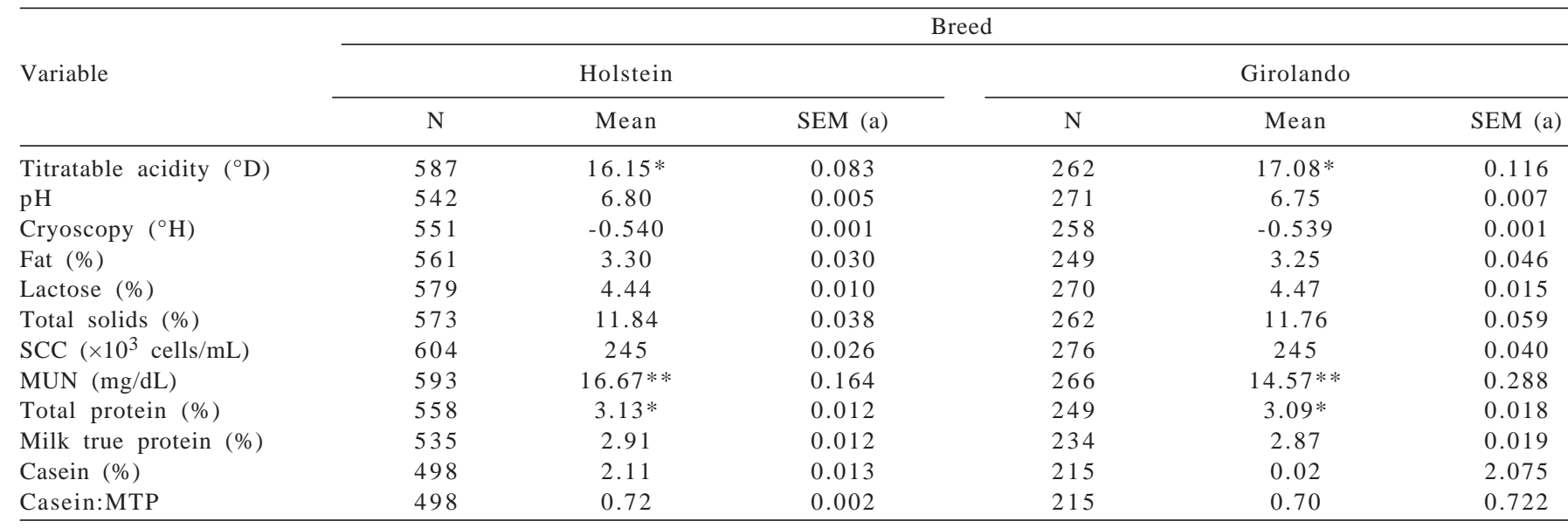

(a) Standard mean error. ${ }^{*} \mathrm{P}<0.05 ; * * \mathrm{P}<0.01$.

Table 5 - Distribution of stable and unstable milk samples, according to stability and $k$-casein polymorphism

\begin{tabular}{|c|c|c|c|c|c|}
\hline \multirow[t]{2}{*}{ Genotype } & \multicolumn{2}{|c|}{ Unstable } & \multicolumn{2}{|c|}{ Stable } & \multirow[t]{2}{*}{ Total } \\
\hline & Observed & Expected & Observed & Expected & \\
\hline AA & 191 (31.83\%) & 182.94 & $409(68,17 \%)$ & 417,06 & 600 \\
\hline $\mathrm{AB}$ & $75(27.88 \%)$ & 82.02 & $194(72,12 \%)$ & 186,98 & 269 \\
\hline BB & 2 (20\%) & 3.05 & $8(80 \%)$ & 6,95 & 10 \\
\hline Total & \multicolumn{2}{|c|}{$268(30.49 \%)$} & \multicolumn{2}{|c|}{$611(69.51 \%)$} & 879 \\
\hline
\end{tabular}


concentration of ethanol solution used for the test. In the rainy season $74.68 \%$ (312 samples) did not coagulate at any ethanol solution used, when the Chi-square expected frequency was $69.51 \%$. This might be explained by differences in milk composition that normally occur between the dry and rainy seasons, which was also observed in this study, especially regarding the milk nitrogen fraction. Normally, this change occurs because of changes in diet fed to cows, and is inversely related to the variations in milk production. Thus, in general, protein and casein concentrations during the dry season are higher than in the summertime (rainy season). The milk composition can have a decisive impact on its stability, especially in samples with lower casein concentrations, which has greater stability at $72^{\circ} \mathrm{GL}$ ethanol solution (Chavez et al., 2004).

Table 6 - Distribution of stable and unstable milk samples, according to breed and seasonality

\begin{tabular}{|c|c|c|c|c|c|c|}
\hline \multirow[b]{2}{*}{ Breed } & \multicolumn{2}{|c|}{ Unstable } & \multicolumn{2}{|c|}{ Stable } & \multirow[t]{2}{*}{ Total } & \multirow[t]{2}{*}{$\mathrm{P}$} \\
\hline & Observed & Expected & Observed & Expected & & \\
\hline Holstein & 138 (22.89\%) & 183.85 & $465(77.11 \%)$ & 419.15 & 603 & 0.0001 \\
\hline Girolando & $130(47.10 \%)$ & 84.15 & $146(52.90 \%)$ & 191.85 & 276 & \\
\hline \multicolumn{7}{|l|}{ Season } \\
\hline Dry & 189 (33.33\%) & 172.87 & $378(66.67 \%)$ & 394.13 & 567 & 0.014 \\
\hline Rainy & 79 (25.32\%) & 95.13 & 233 (74.68\%) & 216.87 & 312 & \\
\hline Total & \multicolumn{2}{|c|}{268 (30.49\%) } & \multicolumn{2}{|c|}{611 (69.51\%) } & & 879 \\
\hline
\end{tabular}

\section{Conclusions}

The physicochemical characteristics and ethanol milk stability test were not influenced by $k$-casein genetic variants, whether for Holstein or Girolando milk. However, $k$-casein genotypes influenced milk fat of both breeds. Holstein cows yielded more stable milk during the rainy season, with a higher content of milk urea nitrogen than did the Girolando cows. Regardless of the period of the year, the Holstein cows had higher milk crude protein, while titratable acidity was higher for Girolando milk. Concentrations of lactose, total solids, crude protein, milk true protein, casein and the casein:milk true protein ratio were higher during dry season. Cryoscopy values, somatic cell counts and milk urea nitrogen were higher during rainy season, regardless of the breed considered.

\section{Acknowledgements}

The authors thank the Fundação de Amparo a Pesquisa do Estado de São Paulo for the financial support to conduct this study (Grant n ${ }^{\circ}$ 02/12058-9), and José Franchini Garcia Moreno and Lucinéia Mestieri, for their technical assistance.

\section{Literature Cited}

ALEXANDER, L.J.; STEWART A.J.; MACKINLAY A.G. et al. Isolation and characterization of the bovine kappa-casein gene. European Journal Biochemistry, v.178 p.395-401, 1988. ASSOCIATION OF OFFICIAL ANALYTICAL CHEMISTS - AOAC Official methods of analysis. 15.ed. Arlington: AOAC International, 1990. 1260p.
ASSOCIATION OF OFFICIAL ANALYTICAL CHEMISTS AOAC. Official methods of analysis. 16.ed. Arlington: AOAC International, 1995. 1025p.

ARUNVIPAS, P.; DOHOO, I.R.; VANLEEUWEN, J.A. et al. The effect of non-nutritional factors on milk urea nitrogen levels in dairy cows in Prince Edward Island, Canada. Preventive Veterinary Medicine, v.59, n.1-2, p.83-93, 2003.

AULDIST, M.J.; WALSH, B.J.; THOMSON, N.A. Seasonal and lactational influences on bovine milk composition in New Zealand. Journal of Dairy Research, v.65, n.3, p.401-411, 1998.

BANSAL, B.K.; HAMANN, J.; GRABOWSKI, N.T. et al. Variation in the composition of selected milk fraction samples from healthy and mastitic quarters, and its significance for mastitis diagnosis. Journal of Dairy Research, v.72, n.2, p.144-152, 2005.

BARBANO, D.M.; CLARK, J.L.; DUNHAM, C.E. et al. Kjeldahl method for determination of total nitrogen-content of milk collaborative study. Journal of The Association of Official Analytical Chemists, v.73, n.6, p.849-859, 1990.

BENTLEY INSTRUMENTS. Bentley 2000 Operator's manual. Chaska, 1995a. p.77.

BENTLEY INSTRUMENTS. Somacount 300 Operator's manual. Chaska, 1995b. p.12.

BENTLEY. Chemspeck 150: User's guide. Chaska: 1998. p.17.

BOBE, G.; BEITZ, D.C.; FREEMAN, A.E. et al. Effect of milk protein genotypes on milk protein composition and its genetic parameter estimates. Journal of Dairy Science, v.82, n.12, p.2797-2804, 1999.

BOTARO, B.G.; LIMA, Y.V.R.; AQUINO, A.A. et al. Betalactoglobulin polymorphism does not affect physicochemical characteristics and milk stability. Pesquisa Agropecuaria Brasileira, v.42, n.5, p.747-753, 2007.

BRASIL. Ministério da Agricultura, Pecuária e Abastecimento. Regulamento técnico de identidade e qualidade de leite cru refrigerado. In: BRASIL. Ministério da Agricultura, Pecuária e Abastecimento. Instrução normativa n. 51, de 18 de setembro de 2002. Diário Oficial da União, 20 set. 2002. Seção 1, p.13.

BUENO, V.F.F.; MESQUITA, A.J.; NICOLAU, E.S. et al. Contagem de células somáticas: relação com a composição do leite e o período do ano no estado de Goiás, Brasil. Ciência Rural, v.35, n.4, p.848-854, 2005. 
CHAVEZ, M.S.; NEGRI, L.M.; TAVERNA, M.A. et al. Bovine milk composition parameters affecting the ethanol stability. Journal of Dairy Research, v.71, p.201-206, 2004.

CRONIN, M.A.; COCKETT, N. Kappa-casein polymorphisms among cattle breeds and bison herds. Animal Genetics, v.24, n.2, p.135-138, 1993.

DAVIES, D.T.; WHITE, J.C.D. The relation between the chemical composition of milk and the stability of the caseinate complex - 2: Coagulation by ethanol. Journal of Dairy Research, v.25, n.2, p.256-266, 1958.

FEAGAN, J.T.; BAILEY, L.F.; HEHIR, A.F. et al. Coagulation of milk proteins - 1. Effect of genetic variants of milk proteins on rennet coagulation and heat-stability of normal milk. Australian Journal of Dairy Technology, v.72, n.4, p.129-134, 1972.

FOX, P.F.; BRODKORB, A. The casein micelle: historical aspects, current concepts and significance. International Dairy Journal, v.18, n.7, p.677-684, 2008.

HAENLEIN, G.F.W.; GONYON, D.S.; MATHER, R.E. et al. Associations of bovine blood and milk polymorphisms with lactation traits - Guernseys. Journal of Dairy Science, v.70, n.12, p.2599-2609, 1987.

HALLEN, E.; WEDHOLM, A.; ANDREN, A. et al. Effect of betacasein, kappa-casein and beta-lactoglobulin genotypes on concentration of milk protein variants. Journal of Animal Breeding and Genetics, v.125, n.2, p.119-129, 2008.

IMAFIDON, G.I.; NG-KWAI-HANG, K.F.; HARWALKAR, V.R. et al. Effect of genetic-polymorphism on the thermal-stability of beta-lactoglobulin and kappa-casein mixture. Journal of Dairy Science, v.74, p.1791-1802, 1991.

JANU, L.; HANUS, O.; FRELICH, J. et al. Influences of different milk yields of Holstein cows on milk quality indicators in the Czech republic. Acta Veterinaria Brno, v.76, n.4, p.553-561. 2007.

LYNCH, J.M.; BARBANO, D.M.; FLEMING, J.R. Indirect and direct determination of the casein content of milk by Kjeldahl nitrogen analysis: collaborative study. Journal of AOAC International, v.81, n.4, p.763-774, 1998.

LINDMARK-MÅNSSON, H.; FONDEN, R.; PETTERSSON, H. Composition of Swedish dairy milk. International Dairy Journal, v.13, n.6, p.409-425, 2003.

MARTINS, P.R.G.; SILVA, C.A.; FISCHER, V. et al. Produção e qualidade do leite na bacia leiteira de Pelotas-RS em diferentes meses do ano. Ciência Rural, v.36, n.1, p.209-214, 2006.

MOLINA, L.H; KRAMM, J.; BRITO, C. et al. Protein composition of milk from Holstein-Friesian dairy cows and its relationship with the genetic variants $\mathrm{A}$ and $\mathrm{B}$ of kappa-casein and betalactoglobulin. International Journal of Dairy Technology, v.59, p.183-187, 2006.

NG-KWAI-HANG, K.F.; MONARDES, H.G.; HAYES, J.F. Association between genetic polymorphism of milk proteins and production traits during three lactations. Journal of Dairy Science, v.73, n.12, p.3414-3420, 1990.

NG-KWAI-HANG, K.F. A review of the relationship between milk protein polymorphism and milk composition/milk production. In: IDF SEMINAR, 1997, Palmerston North. Proceedings... Bruxelles: International Dairy Federation, 1997. p.22-37.

NG-KWAI-HANG, K.F. Genetic polymorphism of milk proteins: Relationships with production traits, milk composition and technological properties. Canadian Journal of Animal Science, v.78, suplemento S., p.131-147, 1998.

O’CONNELL, J.E.; KELLY, A.L.; FOX, P.F. et al. Mechanism for the ethanol-dependent heat-induced dissociation of casein micelles. Journal of Agricultural and Food Chemistry, v.49, n.9, p.4424-4428, 2001.

ONER, Y.; ELMACI, C. Milk protein polymorphisms in Holstein cattle. International Journal of Dairy Technology, v.59, n.3, p.180-182, 2006.
PATERSON, G.R.; MACGIBBON, A.K.H.; HILL, J.P. Influence of kappa-casein and beta-lactoglobulin phenotype on the heat stability of milk. International Dairy Journal, v.9, n.3-6, p.375-376, 1999.

PEREIRA, D.B.C.P.; SILVA, P.H.F.; COSTA JR., L.C.G. et al. Físicoquímica do leite e derivados - Métodos analíticos. Juiz de Fora: EPAMIG, 2001. 234p.

PONCE, P.C.; HERNÁNDEZ, R. Propriedades físicoquímicas do leite e sua associação com transtornos metabólicos e alterações na glândula mamária. In: GONZÁLEZ, F.H.D.; DÜRR, J.W.; FONTANELI, R.S. (Eds.). Uso do leite para monitorar a nutrição e metabolismo de vacas leiteiras. Porto Alegre: UFRGS, 2001. p.58-68.

RIBAS, N.P.; HARTMANN, W.; MONARDES, H.G. et al. Milk total solids in bulk tank samples of Parana, Santa Catarina and São Paulo states. Revista Brasileira de Zootecnia, v.33, n.6, p.2343-2350, 2004.

RIJNKELS, M. Multispecies comparison of the casein gene loci and evolution of casein gene family. Journal of Mammary Gland Biology Neoplasia, v.7, p.327-345, 2002.

ROBITAILLE, G. Influence of kappa-casein and beta-lactoglobulin genetic variants on the heat stability of milk. Journal of Dairy Research, v.62, n.4, p.593-600, 1995.

RODAS, A.C.; ISEPON, J.S.; ALVES, J.B. et al. Efeito da sazonalidade na qualidade do leite "in natura" em Pereira Barreto (SP). In: REUNIÃO ANUAL DA SOCIEDADE BRASILEIRA DE ZooteCniA, 36., 1999, Porto Alegre. Anais... Porto Alegre: Sociedade Brasileira de Zootecnia, 1999. (CD-ROM).

SAMBROOK, J.; FRITSCH, E.F.; MANIATIS, T. Molecular cloning: a laboratory manual. 2.ed. New York: Cold Spring Harbor Laboratory Press, 1989. 3v. 545p.

SANTOS, M.V.; FONSECA, L.F.L. Estratégias para o controle da mastite e melhoria da qualidade do leite. Barueri: Manole, 2006. 314p.

SCHUKKEN, Y.H.; FULTON, C.D.; LESLIE, K.E. Freezing-point of bulk milk in Ontario - an observational study. Journal of Food Protection, v.55, n.12, p.995-998, 1992.

SILVA, P.H.F. Leite UHT: Fatores determinantes para sedimentação e gelificação. 2003. 147f. Tese (Doutorado em Ciência dos Alimentos) - Universidade Federal de Lavras, Lavras, 2003.

SILVA, I.T.; DEL LAMA, M.A. Milk protein polymorphisms in Brazilian zebu cattle. Brazilian Journal of Genetics, v.20, n.4, p.625-630, 1997.

SINGH, H. Heat stability of milk. International Journal of Dairy Technology, v.57, n.2-3, p.111-119, 2004.

STATISTICAL ANALYSIS SYSTEM - SAS. SAS user's guide for Windows: Statistics. Version 8.02. Cary: SAS Institute, 2001. (CD-ROM).

STEVANOVIC, M.; STANOJCIC, S.; DJUROVIC, J. et al. Molecular marker technologies and selection for the traits of economic interest. Biotechnology in animal husbandry, v.16, n.1-2, p.25-34, 2000.

TEIXEIRA, N.M.; FREITAS, A.F.; BARRA, R.B. Influência de fatores de meio ambiente na variação mensal da composição e contagem de células somáticas do leite em rebanhos no Estado de Minas Gerais. Arquivo Brasileiro de Medicina Veterinária e Zootecnia, v.55, n.4, p.491-499, 2003.

TEODORO, R.L.; MADALENA, F.E. Dairy production and reproduction by crosses of Holstein, Jersey or Brown Swiss sires with Holstein-Friesian/Gir dams. Tropical Animal Health and Production, v.35, n.2, p.105-115, 2003.

VERNEQUE, R.S.; MARTINEZ, M.L.; BRITO, J.R.F. et al. Constituintes do leite nas raças Gir e Guzerá leiteiras. In: CARVALHO, L.A.; ZOCCAL, R.; MARTINS, P.C. et al. (Eds.). Tecnologia e gestão na atividade leiteira. Juiz de Fora: Embrapa Gado de Leite, 2005. p.323. 